\title{
Dental pain prevalence among health care personnel*
}

\author{
Prevalência de dor dentária em trabalhadores da saúde \\ Ludmilla Awad Barcellos ${ }^{1}$, André Carnielli Uliana ${ }^{2}$, Maria Helena Monteiro de Barros Miotto ${ }^{2}$, Eliete Rodrigues de Almeida ${ }^{3}$
}

${ }^{*}$ Received from Federal University of Espírito Santo, Vitória, ES, Brazil.

DOI 10.5935/1806-0013.20150023

\section{ABSTRACT}

BACKGROUND AND OBJECTIVES: Dental pain is a major reason for looking for dental services. Toothache may prevent or impair daily activities, such as working, having fun or socializing. This study aimed at evaluating dental pain prevalence in the last six months, among employees of the Teaching Hospital, Vitoria, ES.

METHODS: This was an analytical, observational cross-sectional study. Data were collected by six trained interviewers by means of standardized interviews filling a questionnaire previously used by other studies about toothache among employees of the state of Espirito Santo, which included demographic and social information, as well as toothache report, type of pain (spontaneous or induced), use of dental services and employment bond. Confidence level of $95 \%$, error of $5 \%$ and expected prevalence of $50 \%$ were used for sample calculation. Final sample was made up of 265 employees. The association between studied variables and dental pain prevalence was observed using Pearson Chi-square test with significance level of 5\%. Odds Ratio and respective confidence intervals (CI95\%) were estimated for statistically significant variables.

RESULTS: Dental pain prevalence was $65.7 \%$. Employees with up to 39 years of age $(\mathrm{p}=0.004, \mathrm{OR}=2.081$ CI $95 \%=1.226$; $3.530)$, of economic classes $\mathrm{C}$ and $\mathrm{D}(\mathrm{p}=0.007, \mathrm{OR}=1.968 \mathrm{CI}$ $95 \%=1.173 ; 3.30)$ and those receiving up to three minimum wages have reported higher dental pain prevalence $(\mathrm{p}=0.000$, $\mathrm{OR}=2.829 \mathrm{CI}=1.611$; 4.967).

CONCLUSION: There has been high dental pain prevalence among employees. Strategies to decrease such event should be implemented aiming at improving quality of life of such employees. Keywords: Dental pain, Employees' health, Health professionals, Oral health.

1. University of Vila Velha, Vitória, ES, Brazl.

2. Federal University of Espírito Santo, Vitória, ES, Brazil.

3. University Cruzeiro do Sul, Sáo Paulo, SP, Brazil.

Submitted in November 24, 2014.

Accepted for publication in May 20, 2015.

Conflict of interests: none - Sponsoring sources: none.

Correspondence to:

Ludmilla Awad Barcellos

Av. Marechal Campos 1468 - Maruípe

29040-091 Vitória, ES, Brasil.

E-mail: ludawad@oi.com.br

(c) Sociedade Brasileira para o Estudo da Dor

\section{RESUMO}

JUSTIFICATIVA E OBJETIVOS: A dor de origem dental é um dos principais motivos da utilização de serviços odontológicos. A dor de dente pode impedir ou dificultar atividades diárias, tais como trabalhar, se divertir e se relacionar com outras pessoas. $\mathrm{O}$ objetivo deste estudo foi verificar a prevalência de dor de origem dental nos últimos seis meses em funcionários do Hospital Universitário, Vitória, ES.

MÉTODOS: Foi realizado um estudo analítico, do tipo observacional com delineamento transversal. Seis entrevistadores treinados coletaram os dados pelo método de entrevista padronizada preenchendo um questionário previamente utilizado em outros estudos sobre dor de dente em trabalhadores capixabas que incluía informaçóes demográficas e sociais dos participantes, bem como o relato de dor de dente, tipo de dor (espontânea ou provocada), utilização de serviços odontológicos e tipo de vínculo empregatício. Para o cálculo amostral, os parâmetros utilizados foram nível de confiança de $95 \%$, erro de $5 \%$ e prevalência esperada de 50\%. A amostra final foi de 265 funcionários. A associação entre as variáveis do estudo e a prevalência de dor de dente foi verificada por meio do teste Qui-quadrado de Pearson com nível de significância de 5\%. Estimaram-se os valores do Odds Ratio e respectivos intervalos de confiança (IC-95\%) para as variáveis com significância estatística.

RESULTADOS: A prevalência de dor de origem dental foi de $65,7 \%$. Funcionários com até 39 anos $(\mathrm{p}=0,004, \mathrm{OR}=2,081$ IC95\%=1,226; 3,530), inseridos nas classes econômicas C e D, $(\mathrm{p}=0,007, \mathrm{OR}=1,968$ IC $95 \%=1,173 ; 3,30)$ e aqueles que recebiam até 3 salários mínimos relataram maior prevalência de dor de origem dental ( $p=0,000, \mathrm{OR}=2,829 \mathrm{IC}=1,611$; 4,967).

CONCLUSÁO: Observou-se alta prevalência de dor de dente em funcionários. Estratégias direcionadas à redução do evento devem ser implementadas com vistas à melhora da qualidade de vida desses trabalhadores.

Descritores: Profissionais da saúde, Odontalgia, Saúde bucal, Saúde do trabalhador.

\section{INTRODUCTION}

Dental pain is the most impacting oral disease and is considered public health problem due to its high prevalence, for being preventable and for the major impact on daily lives of people. For individuals in productive age, dental pain may generate productivity loss, prevent or impair daily activities, such as working, having fun and relating to other people ${ }^{1}$. 
Epidemiological studies also show that toothache is a major reason for looking for dental services due to potential distress generated to individuals ${ }^{2}$.

According to National Survey by Home Sample (PNAD) ${ }^{3}$ data, it is estimated that 29.6 million people $(18.7 \%$ of Brazilian population) have never been to a dentist ${ }^{3}$. This number has decreased in a survey from 2003 where $15.9 \%$ of Brazilians have stated never having been to dental office. In the state of Espirito Santo, numbers are also alarming: $15.23 \%(503,764$ people $)$ have never been to a dentist ${ }^{3}$.

PNAD data (2008) showed increased access to dental services; however $11.67 \%$ are still excluded from the service ${ }^{4}$. In a recent national survey on oral health conditions, it was observed that $23 \%$ of all respondents have reported dental pain in the six months previous to the survey. This percentage was decreased to $10 \%$ among the elderly aged from 65 to 74 years, probably due to teeth loss 5 .

Toothache is considered a difficulty faced by populations and individuals who do not find in health services adequate means for oral health care and adopt self-medication as alternative to solve the suffering ${ }^{6}$.

This study aimed at evaluating toothache prevalence among employees of a Teaching Hospital in Vitoria, ES.

\section{METHODS}

The Teaching Hospital Cassiano Antonio Moraes (HUCAM) is currently considered the largest public hospital of Espirito Santo, considering the number of performed procedures, especially those of high complexity. It is located in the district of Maruipe, city of Vitoria. Its coverage goes beyond the state of Espirito Santo, receiving patients especially from the states of Bahia and Minas Gerais.

This analytical, observational study used a crossover design. This study design refers to a single point in time where "cause" and "effect" are simultaneously evaluated.

A representative sample of employees linked to HUCAM (effective and/or outsourced) was randomly selected from a universe of 960 individuals. Sample calculation parameters were confidence level of $95 \%$, error of $5 \%$ and expected prevalence of $50 \%$, resulting in $n$ of 300 employees.

Inclusion criteria were being HUCAM worker, aged between 18 and 60 years. Employees on medical or disability leave were excluded.

Toothache was the outcome considered in the study. Statistical analysis has evaluated possible association among independent variables: gender, age group, income, socioeconomic condition (SEC) and education level.

Six trained interviewers have collected data by the standardized interview method filling a questionnaire about toothache previously used by other studies with workers of the state of Espirito Santo. Items included participants' demographic and social information, as well as toothache report (spontaneous or provoked), use of dental services and type of employment relationship. Participants' socioeconomic classification has followed Brazil Economic Classification Criteria, which establishes cutoff points based on the ownership of assets declared by respondents. Data were analyzed by frequency tables with absolute and percentage numbers for each survey tool item. Data analysis has used Pearson Chi-square test with significance level of 5\%. Odds Ratio (OR) and respective 95\% confidence interval were estimated to check the magnitude of the association. Statistical package SPSS - Statistical Package for the Social Sciences, version 15 was used for analyses.

The study was approved by the Research Ethics Committee, Federal University of Espirito Santo under protocol $110 / 2010$.

\section{RESULTS}

The study got a final sample of 265 validated questionnaires, recording a loss of $11.66 \%$. Most employees were females, between 30 and 49 years of age, with education level above high school, inserted in economic classes B and C, income between 2-6 minimum wages, and employment relationship by means of public tender (Table 1).

Table 1. Socio-demographic data of health employees, 2011

\begin{tabular}{|c|c|c|}
\hline Characterístics & Number & Percentage \\
\hline \multicolumn{3}{|l|}{ Gender } \\
\hline Female & 210 & 79.2 \\
\hline Male & 55 & 20.8 \\
\hline \multicolumn{3}{|l|}{ Age group (years) } \\
\hline Up to 29 & 51 & 19.2 \\
\hline $30-39$ & 67 & 25.3 \\
\hline $40-49$ & 80 & 30.2 \\
\hline 50 or above & 67 & 25.3 \\
\hline \multicolumn{3}{|l|}{ Marital status } \\
\hline Single & 113 & 42.6 \\
\hline Married & 116 & 43.7 \\
\hline Divorced & 25 & 9.4 \\
\hline Widow/er & 11 & 4.2 \\
\hline \multicolumn{3}{|l|}{ Education level } \\
\hline Illiterate and up to ${ }_{3 r d}$ grade of BE & 10 & 3.8 \\
\hline $4^{\text {th }}$ grade to $7^{\text {th }}$ grade of $B R$ & 26 & 9.8 \\
\hline Incomplete high school & 34 & 12.8 \\
\hline Incomplete college & 127 & 47.9 \\
\hline Complete college & 68 & 25.7 \\
\hline \multicolumn{3}{|l|}{ Socioeconomic condition } \\
\hline Class A & 15 & 5.7 \\
\hline Class B & 119 & 44.9 \\
\hline Class C & 122 & 46.0 \\
\hline Class D & 9 & 3.4 \\
\hline
\end{tabular}


Table 1. Socio-demographic data of health employees, 2011 - continuation

\begin{tabular}{lcc}
\hline Characterístics & Number & Percentage \\
\hline Family income & & \\
Up to 2 MW & 63 & 23.8 \\
More than 2 to 3 MW & 58 & 21.9 \\
More than 3 to 6 MW & 79 & 29.8 \\
More than 6 MW & 37 & 14.0 \\
Refused to inform & 28 & 10.6 \\
Type of employment relation & & \\
Outsourced & 97 & 36.6 \\
By public tender & 168 & 63.4 \\
Total & 265 & 100.0 \\
\hline
\end{tabular}

$\mathrm{BE}=$ basic education, $\mathrm{MW}=$ minimum wage.

Prevalence of reported toothache was $65.7 \%$ for the last six months. Pain has determined the use of dental services for $46.6 \%$ of subjects. Observing the number of visits to the dentist, $45.7 \%$ needed three visits or more to solve the episode, which may suggest more complexity of the event or questionable resolution of the service. Considering the number of individuals not looking for assistance, unawareness of the need has been the primary barrier for using the service (Table 2).

Table 3 shows the association of dental pain and sociodemographic variables of health professionals of a teaching hospital of UFES, city of Vitoria/ES.

Table 2. Data on toothache among health employees, 2011

\begin{tabular}{|c|c|c|}
\hline Characteristics & Number & Percentage \\
\hline \multicolumn{3}{|l|}{ Had dental pain } \\
\hline Yes & 174 & 65.7 \\
\hline No & 91 & 34.3 \\
\hline \multicolumn{3}{|l|}{ Type of pain } \\
\hline Provoked & 97 & 55.7 \\
\hline Spontaneous & 20 & 11.5 \\
\hline Provoked and spontaneous & 57 & 32.8 \\
\hline \multicolumn{3}{|l|}{ Used dental service due to pain } \\
\hline Yes & 81 & 46.6 \\
\hline No & 93 & 53.4 \\
\hline \multicolumn{3}{|l|}{ Number of visits to dentist } \\
\hline Once & 29 & 35.8 \\
\hline Twice & 15 & 18.5 \\
\hline Three or more & 37 & 45.7 \\
\hline \multicolumn{3}{|l|}{ Reason for not using dental services } \\
\hline Fear & 5 & 5.4 \\
\hline Unaware of the need & 56 & 60.2 \\
\hline Was not allowed by the company & 1 & 1.1 \\
\hline Cost & 8 & 8.6 \\
\hline No service at the Health Unit & 3 & 3.2 \\
\hline Dissatisfaction with previous treatment & 3 & 3.2 \\
\hline No justification & 17 & 18.3 \\
\hline
\end{tabular}

Table 3. Association of dental pain and sociodemographic factors of health employees, 2011

\begin{tabular}{|c|c|c|c|c|c|c|}
\hline \multirow[t]{2}{*}{ Characteristics } & \multicolumn{2}{|c|}{ Pain } & \multicolumn{2}{|c|}{ No pain } & \multirow[t]{2}{*}{$p$-value } & \multirow[t]{2}{*}{ Odds Ratio } \\
\hline & $n^{\circ}$ & $\%$ & $\mathrm{n}^{\circ}$ & $\%$ & & \\
\hline \multicolumn{7}{|l|}{ Gender } \\
\hline Female & 140 & 66.7 & 70 & 33.3 & \multirow[t]{2}{*}{0.301} & 1.235 \\
\hline Male & 34 & 61.8 & 21 & 38.2 & & $0.668-2.285$ \\
\hline \multicolumn{7}{|l|}{ Age group (years) } \\
\hline Up to 39 & 88 & 74.6 & 30 & 25.4 & \multirow[t]{2}{*}{0.004} & 2.081 \\
\hline 40 or above & 86 & 58.5 & 61 & 41.5 & & 1.2 \\
\hline \multicolumn{7}{|l|}{ Marital status } \\
\hline Single & 78 & 69.0 & 35 & 31.0 & \multirow[t]{2}{*}{0.194} & 1.300 \\
\hline Others & 96 & 63.2 & 56 & 36.8 & & 0.7 \\
\hline \multicolumn{7}{|l|}{ Education level } \\
\hline Up to IHS & 47 & 67.1 & 23 & 32.9 & \multirow[t]{2}{*}{0.440} & 1.094 \\
\hline CHS or above & 127 & 65.1 & 68 & 34.9 & & \\
\hline \multicolumn{7}{|c|}{ Socioeconomic condition } \\
\hline $\mathrm{A} / \mathrm{B}$ & 78 & 58.2 & 56 & 41.8 & \multirow[t]{2}{*}{0.007} & 1.968 \\
\hline$C / D$ & 96 & 73.3 & 35 & 26.7 & & $1.173-3.300$ \\
\hline \multicolumn{7}{|l|}{ Family income } \\
\hline Up to $3 \mathrm{MW}$ & 94 & 77.7 & 27 & 22.3 & \multirow[t]{2}{*}{0.000} & 2.829 \\
\hline More than $3 \mathrm{MW}$ & 64 & 55.2 & 52 & 44.8 & & $1.611-4.967$ \\
\hline \multicolumn{7}{|l|}{ Type of employment } \\
\hline Outsourced & 70 & 72.2 & 27 & 27.8 & \multirow[t]{2}{*}{0.059} & \multirow{2}{*}{$\begin{array}{c}1.595 \\
0.928-2.744\end{array}$} \\
\hline By public tender & 104 & 61.9 & 64 & 38.1 & & \\
\hline
\end{tabular}

IHS = incomplete high school, $\mathrm{CHS}=$ complete high school, $\mathrm{MW}=$ minimum wage.

Dental pain prevalence was associated to age group, socioeconomic condition and income. Individuals up to 39 years of age had twice more chance of having toothache $(\mathrm{OR}=2.081$, CI95\% $=1.226-3.530$ ).

Workers of less favored economic classes had almost twice the chance of having toothache $(\mathrm{OR}=1.968, \mathrm{CI} 95 \%=1.173$; 3.300).

Similarly, those stating family income of up to three minimum wages had 2.8 times more chance of pain $(\mathrm{OR}=2.829$, CI $95 \%=1.611 ; 4.967)$.

\section{DISCUSSION}

Dental pain prevalence in this study was $65.7 \%$, result evaluated as surprising considering that the sample was made up of employees of a teaching hospital nearby Dentistry course clinics. This result is higher than those found in the State, in the Southeastern region and in Brazil. In a sample of public servants in Venda Nova do Imigrante, $\mathrm{ES}^{7}$, and Marataizes ${ }^{8}$ prevalences were 43 and 57\%, respectively. In a food industry in the Southeastern region there has been $46.7 \%$ prevalence of pain $^{2}$. The latest national survey has indicated a frequency of $27.5 \%$ for Brazil and of $30.8 \%$ for the Southeastern region in the population between 35 and 44 years of age ${ }^{5}$. All above-mentioned studies have measured 
toothache frequency in the last six months.

Participants of this survey had complimentary dental service offered by the university and close to the hospital. It was expected that this fact would positively impact the frequency of such pain episodes by decreasing it. It is known that the use of dental services may be influenced by several variables and that service availability is not always able to generate demand. Other features might be involved with perception of the need, in addition to cultural factors and health beliefs ${ }^{2}$ Some studies show huge variations in pain prevalence due to the time period respondents have reported having dental pain, as well as to different oral health conditions presented by participants ${ }^{9}$. A study carried out in Rio de Janeiro has found a very low prevalence of approximately $2.9 \%$ among employees of a university, difference explained by the fact that reported pain period was the last two weeks ${ }^{10}$.

With regard to age group, this study has found higher pain prevalence among employees aged up to 39 years, in line with the national study which has found age as a determining factor for pain ${ }^{11}$, and different from studies carried out in Espirito Santo ${ }^{2.7,8}$. Comparison with some studies might be impaired by different cutoff points used to select the groups ${ }^{12-14}$. In terms of income, this study has observed higher pain prevalence among those with reported income of up to three minimum wages, differently from other studies carried out in the region ${ }^{2,7,8}$. Similar results were found for different Brazilian regions: Recife ${ }^{13}$, Rio de Janeiro ${ }^{10}$ and Southern Brazil ${ }^{12,15}$. This study has found higher reported pain prevalence among employees of economic classes $\mathrm{C}$ and $\mathrm{D}$, in line with other studies results ${ }^{2,16}$. In light of the strong association of oral diseases and social components, SEC might be a factor influencing the maintenance of oral health care, thus contributing to prevent dental pain ${ }^{16}$.

Although considering toothache prevalence very high, it was enough to generate dental service use by just $46.6 \%$ of those reporting toothache in the last six months. This result is in line with those found by different studies, confirming that toothache is not always enough to generate service de$\operatorname{mand}^{17,18}$. This fact should be better evaluated by further studies investigating not only the type of pain but also its intensity and frequency.

Studies involving estimates of health services usage should try to identify possible barriers for the usage with focus on the implementation of measures aimed at improving the access of communities. Studies have shown that the lack of perceived need by people has been one of the major barriers for the use $\mathrm{in}^{17,19,20}$. Other associated variables are fear, cost and factors related to poor organization of the local health service. In our study, results have shown that among 93 subjects $(53.4 \%)$ reporting not having used dental services during the pain episode, unawareness of the need was reported as the most frequent reason $(60.2 \%)$ for not looking for the service. This fact might be "masking" the possibility of selfmedication, a very common practice in our society and still potentially encouraged by the ease with which health employees get drugs.
A study carried out in an emergency dental service in Minas Gerais has observed self-medication prevalence of $79.3 \%$ of users of such service ${ }^{21}$. The Brazilian Association of Pharmaceutical Industries (ABIFARMA) estimates that 80 million people practice self-medication ${ }^{22}$. This is a worrisome public health problem and may be an indicator of the barrier for using health services ${ }^{22}$. Notwithstanding the scarcity of studies evaluating self-medication for dental pain episodes, a study carried out in Recife has confirmed this attitude as routine among families whose children had toothache ${ }^{13}$. In Rio Grande do Sul, 72.6\% of individuals looking for urgency services have reported using drugs previously to looking for professional help ${ }^{23}$.

Health promotion policies aiming at informing and improving the access to routine dental services should be implemented. Toothache is a very frequent event in Brazil ${ }^{13,23}$ and leads to absenteeism ${ }^{2,7,8}$ and strong impact on quality of life $\mathrm{l}^{14}$.

\section{CONCLUSION}

The prevalence of dental pain among HUCAM, Vitoria, ES employees may be considered high and worrisome. Younger employees of less favored classes, with income below three minimum wages were those reporting the highest prevalence of toothache. Strategies toward decreasing this event should be implemented aiming at improving quality of life of these employees.

\section{REFERENCES}

1. Locker D, Grushka M. The impact of dental and facial pain. J Dent Res. 1987;66(9):1414-7.

2. Miotto MH, Barcellos LA, Lopes ZV. [Dental pain as a predictor of absenteeism among workers in a juice factory in southeastern Brazil]. Cienc Saude Colet. 2013;18(11):3183-90. Portuguese.

3. Brasil. Instituto Brasileiro de Geografia e Estatística. Pesquisa Nacional por Amostra de Domicílios, 1998. [citado 2011 maio 29]. Disponível em: http://www.ibge.gov.br/ home/estatistica/populacao/trabalhoerendimento/pnad98/saude/analise.shtm.

4. Brasil. Instituto Brasileiro de Geografia e Estatística. Pesquisa Nacional por Amostra de Domicílios, 2008. [citado 2014 novembro 19]. Disponível em: http://www.ibge. gov.br/home/estatistica/populacao/trabalhoerendimento/pnad2008.pdf

5. Brasil. Ministério da Saúde. Secretaria de Atenção à Saúde. Departamento de Atenção Básica. Projeto SB Brasil 2010: pesquisa nacional de saúde bucal - resultados principais. Brasília: Ministério da Saúde; 2011. 90p. www.idisa.org.br/.../SAUDE\%20 BUCAL--NotaParaImprensa-28dez2010.

6. Ferreira AA, Piuvezam G, Werner CW, Alves MS. A dor e a perda dentária: representaçốes sociais do cuidado à saúde bucal. Ciên Saúde Coletiva. 2006;11(1):211-8.

7. Miotto MH, Silotti JC, Barcellos LA. [Dental pain as the motive for absenteeism in a sample of workers]. Cienc Saude Colet. 2012;17(5):1357-63. Portuguese.

8. Miotto MH, Lima WJ, Barcellos LA. Association between pain and absenteeism among public workers from Southeastern Brazil. Rev Dor. 2014;15(3):173-7.

9. Pau AK, Croucher R, Marcenes W. Prevalence estimates and associated factors for dental pain: a review. Oral Health Prev Dent. 2003;1(3):209-20.

10. Alexandre GC, Nadanosvky P, Lopes CS, Faerstein E. [Prevalence and factors associated with dental pain that prevents the performance of routine tasks by civil servants in Rio de Janeiro, Brazil]. Cad Saude Publica. 2006;22(5):1073-8. Portuguese.

11. Peres MA, Iser BP, Peres KG, Malta DC, Antunes JL. [Contextual and individual inqualities in dental pain prevalence among Brazilian adults and elders]. Cad Saude Publica. 2012;28(Suppl):S114-23. Portuguese.

12. Nomura LH, Bastos JL, Peres MA. [Dental pain prevalence and association with dental caries and socioeconomic status in schoolchildren, Southern Brazil]. Braz Oral Res. 2004;18(2):134-40. Portuguese.

13. Goes PS, Watt R, Hardy RG, Sheiham A. The prevalence and severity of dental pain in 14-15 year old Brazilian schoolchildren. Community Dent Health. 2007;24(4):217-24

14. de Oliveira BH, Nadanovsky P. The impact of oral pain on quality of life in lowincome Brazilian women. J Orofac Pain. 2006;20(4):297-305. 
15. Bastos JL, Nomura LH, Peres MA. [Dental pain, socioeconomic status, and dental caries in young male adults from Southern Brazil]. Cad Saude Publica. 2005;21(5):141623. Portuguese.

16. Oliveira BA, Biazevic MG, Michel-Crosato E. Prevalência de dor de dente, cárie dental e condiçóes socioeconômicas: um estudo em adultos jovens brasileiros. Odonto. 2011;19(38):7-14.

17. Barcellos LA, Loureiro CA. O público do serviço odontológico. UFES Rev Odontol. 2004;6(2):4-10.

18. Lacerda, JT, Simionato EM, Peres KG, Peres MA, Traebert J, Marcenes W. [Dental pain as the reason for visiting a dentist in a Brazilian adult population]. Rev Saude Publica. 2004;38(3):453-8. Portuguese.

19. Rohr RIT, Barcellos LA. As barreiras de acesso para os serviços odontológicos. UFES Rev Odontol. 2008;10(3):37-41
20. Miranda CD, Peres MA. [Determinants of dental services utilization by adults: a population-based study in Florianópolis, Santa Catarina State, Brazil]. Cad Saude Publica. 2013;29(11):2319-32. Portuguese.

21. Tamietti MB, Martins MA, Abreu MH, Castilho LS. Fatores associados a automedicaçấo em um serviço brasileiro de emergência odontológica. Pesq Bras Odontoped Clin Integ. 2012;12(1):65-9.

22. Silva RA, Marques FD, de Goes PS. [Factors associated with self-medication for toothache: analysis using pharmacy personnel in the city of Recife, PE]. Cienc Saude Colet. 2008;13(Suppl):697-701. Portuguese.

23. De-Paula KB, Silveira LS, Fagundes GX, Ferreira MB, Montagner F. Patient automedication and professional prescription pattern in an urgency service in Brazil. Braz Oral Res. 2014;28(1):1-6. 